\title{
COMPARATIVE STEREOLOGIC STUDY BETWEEN SECRETORY AND MATURATION AMELOBLASTS IN RAT INCISORS
}

\author{
ESTUDO ESTEREOLÓGICO COMPARATIVO ENTRE OS AMELOBLASTOS DE \\ SECREÇÃO E DE MATURAÇÃO EM INCISIVOS DE RATOS
}

\author{
Gerson Francisco de ASSIS \\ Professor Assistente Doutor do Departamento de Ciências Biológicas da Faculdade de Odontologia de Bauru/USP. \\ Daniel Araki RIBEIRO \\ Doutorando em Patologia na Faculdade de Medicina de Botucatu/UNESP. \\ Patrícia Danieli CAMPOS \\ Bolsista PIBIC/CNPq/FOB/USP. \\ Tania Mary CESTARI \\ Bióloga do Departamento de Ciências Biológicas da Faculdade de Odontologia de Bauru - USP. \\ Rumio TAGA \\ Professor Titular do Departamento de Ciências Biológicas da Faculdade de Odontologia de Bauru - USP.
}

\begin{abstract}
$T$ he ameloblasts both in secretion phase and in smooth-ended ameloblasts in maturation phase were studied using stereologic methods in transmission electron microscopy (TEM). From secretion to maturation phase of amelogenesis, the nucleus volume decreased $23 \%$ and cytoplasm volume did not show significant changes; the total volume and surface of the rough endoplasmic reticulum (RER) decreased $74 \%$ and $90 \%$, respectively, and of the mitochondria increased $742 \%$ and $384 \%$, respectively; the surface-to-volume ratio for RER and mitochondria decrease $59 \%$ and $42 \%$, respectively; and the predominantly apical secretory granules disappeared joined at Tomes' process and lysosomes and phagic vacuoles have appeared principly in supranuclear cytoplasm. Although significant morphologic variation occurs from the secretory to the maturation phase of the ameloblasts, their cytoplasm volume remains unaltered.
\end{abstract}

UNITERMS: Maturation and secretory ameloblasts; Rat incisors; Stereology; Ultrastructure.

\section{INTRODUCTION}

Ameloblasts are ephitelial cells which play crucial role in synthesis, secretion and maturation of the dental enamel. For the fulfilment of these functions, ameloblasts undergo morphologic modulations. During the phase of protein matrix synthesis and secretion, ameloblasts are a longer cell, with ellipsoid nucleus in the basal portion and a great amount of membranes of both rough endoplasmic reticulum (RER) and the Golgi's complex. Secretory granules in the central and apical portion also are seen. The terminal apical portion of the cells is so called Tomes' process $^{8}$. Afterwards, ameloblasts start modulation pattern, which practices enamel maturation. Thus, cell height and volume decrease, the amount of organelles diminishs, Tomes' process disappears ${ }^{19}$ and digestive vacuoles and lysosomal enzymes increase in the cytoplasm $^{21}$. In the maturation phase, ameloblasts are able to modulate, in cyclic pathways, for two morphofuncional types, one type is called smoothended ameloblast, whose apical portion is replete of microvesicles, it takes out role in water and organic material resorption; and other type is named roughended ameloblast, it has apical plasmalena with projections, this morphological type takes out role in introduction of inorganic material in maturing enamel $^{4,8,19,21}$. 
Many trials about this issue look for elucidate amelogenesis ${ }^{8,19,21}$, as well as more specifically the secretion and maturation phases, with focusing to elucidate dental enamel development, using either light microscopy ${ }^{7,14}$ and electron microscopy $y^{2-4,7,8,14-18}$. Furthermore, these two stages of amelogenesis appear to be a comparable phenomenon among mammalian species. There are several important anatomical distinctions in enamel structure among the species that have been examined ${ }^{18}$. Consequently, secretory and maturation phases of amelogenesis are not having been investigated extensively up to now.

In order to improve our understanding about this issue, in the present study, we compared morphologically and stereologically the ameloblasts in secretion and maturation phases of amelogenesis, at ultrastructural level.

\section{MATERIAL AND METHODS}

\section{Animals and Experimental design}

Five male adults rats (Wistar) weighting around $150 \mathrm{~g}$, were used. The rats were anesthetized with $0.5 \mathrm{ml} / \mathrm{kg}$ body weight of xylazine plus and $1.5 \mathrm{ml} / \mathrm{kg}$ body weight of Ketamine and the jaws were fixed by vascular perfusion with $2.5 \%$ glutaraldehyde and $2.5 \%$ paraformaldehyde in $0.1 \mathrm{M}$ sodium cacodylate buffer, $\mathrm{pH} 7.3$, for about $10 \mathrm{~min}$ at room temperature ${ }^{22}$. The lower incisors were then dissected from the jaws and demineralized in $4.13 \%$ EDTA adjusted to $\mathrm{pH} 7.2$ with sodium hydroxide, during which time mature enamel was dissolved ${ }^{20,22}$. Ameloblasts localization in secretory and maturation phase was made, using as reference molar tooth ${ }^{20}$. Incisor fragments with regions of secretory and maturation ameloblasts were postfixed with $1 \%$ osmium tetroxide in the same buffer for $1 \mathrm{~h}$ at $4^{\circ} \mathrm{C}$, dehydrated in ethanol and propylene oxide and embedded in Spurr ${ }^{\mathrm{TM}}$ resin. Ultrathin sections obtained in ultramicrotome Poter-BloomSorval MT-2 were stained with uranyl acetate and lead citrate and examined in EM 900 Zeiss transmission electron microscope.

\section{Stereological analysis}

Examination of ultrathin sections and acquiring of the cells images to electronmicrographs were executed using systematic randomization ${ }^{24,25}$, in nominal 12000X magnification. To evaluate of the cytoplasmic and nuclear volume, semithin sections of $0.5 \mathrm{~mm}$ were stained in methylene blue + azur II, and the images in
1000X magnification were acquired in Zeiss Axioshop photomicroscopy and sent to image analysis system KS300. The higher (D) and smaller (d) diameters of the nuclei were measured and the mean nuclear volume was calculated using the formula: $\mathrm{V}=\frac{\pi}{6} \cdot(D \cdot d \cdot \sqrt{D \cdot d})$.

For obtain the cytoplasm volume, initially we obtained the nuclear and cytoplasmic volume density $(\mathrm{Vv})$ and we made a proportional rule. In 20 electronmicrographs per animal the multipurpose testsystem $^{23,25}$ for counting the number of points and intersections was used to make evaluation of morphometric parameters. The volume density of each structure was calculated by quotient between number of points over each structure and number of points over the cytoplasm. The total volume of each structure was evaluated through their volume density multiplied by the cytoplasmic volume. The surface density of each structure was obtained by quotient between number of intersections with the structure four times and total number of points in the cytoplasm multiplied by size of straight line of the test-system used $(0.9722 \mathrm{~mm})^{24-}$ ${ }^{25}$. The total surface was calculated multiplying their surface density by cytoplasm volume. The surface-tovolume ratio of the strucutre was obtained by quotient between their total surface and total volume ${ }^{23-25}$.

\section{Statistical analysis}

The measures were compared by ANOVA one-way test, using the software SigmaStat - Jadel TM Scientific software for Windows and the level of significance was set at 0.05 .

\section{RESULTS}

\section{Morphological results}

The secretory ameloblasts are tall and prismatic in shape. In the apical portion (Figure 1A) exhibited a great amount of RER, few secretory granules disposed throughout Tomes' process and a region more electrodense representing the junctional complex net. In the basal cytoplasm (Figure 1B) ellipsoid nucleus with one or more nucleolus is evident and a great number of small and longer mitochondria of several configurations occupy the suprabasal region. The small Golgi complex is seen in medial region of the cell.

The maturation ameloblasts present lower height and larger width in respect to secretory ones. Their apical plasmalema (Figure 2A) shows more electrodense projections due to tonofilaments of desmossomes associated to junctional complex. The 
apical cytoplasm (Figure 2A), exhibits large number of mitochondria with several configurations. In the central portion of the cells (Figure 2A), various lysosomes and phagic vacuoles, microfilaments and few amount of membranes of RER and Golgi complex are observed. The basal cytoplasm (Figure 2B) exhibits ellipsoid nucleus, larger phagic vacuoles and spherical mitochondria in higher number than in secretory ameloblasts.

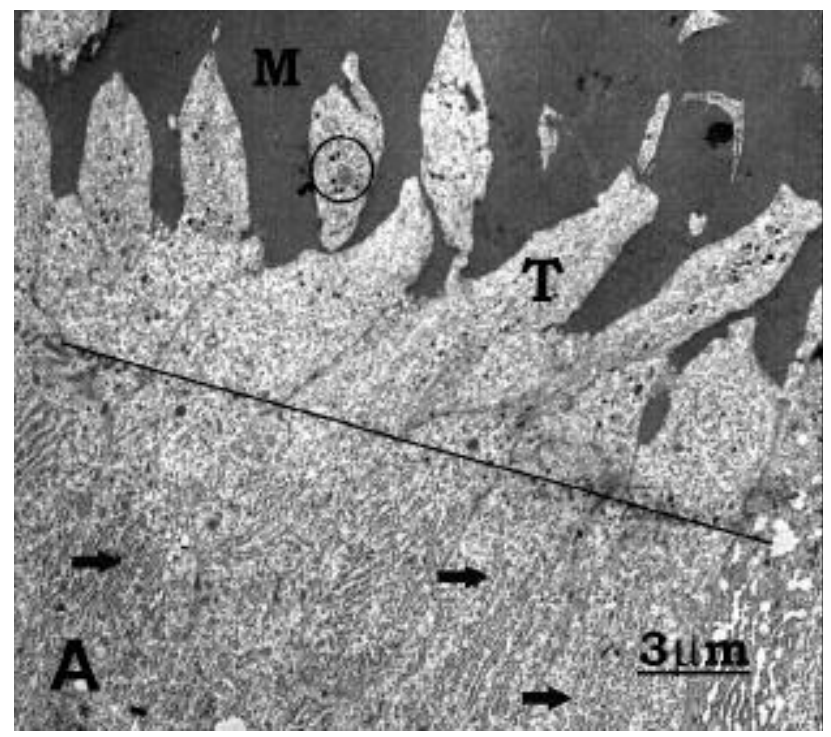

\section{Quantitative results}

All the stereologic results are shown in the Table 1.

The nucleus volume of secretory ameloblasts showed $23 \%$ higher than maturation ones. For the cytoplasmic volume no significant statistical differences $(\mathrm{p}>0.05)$ from secretory to maturation ameloblasts was observed.

In respect to RER, there was a decrease from

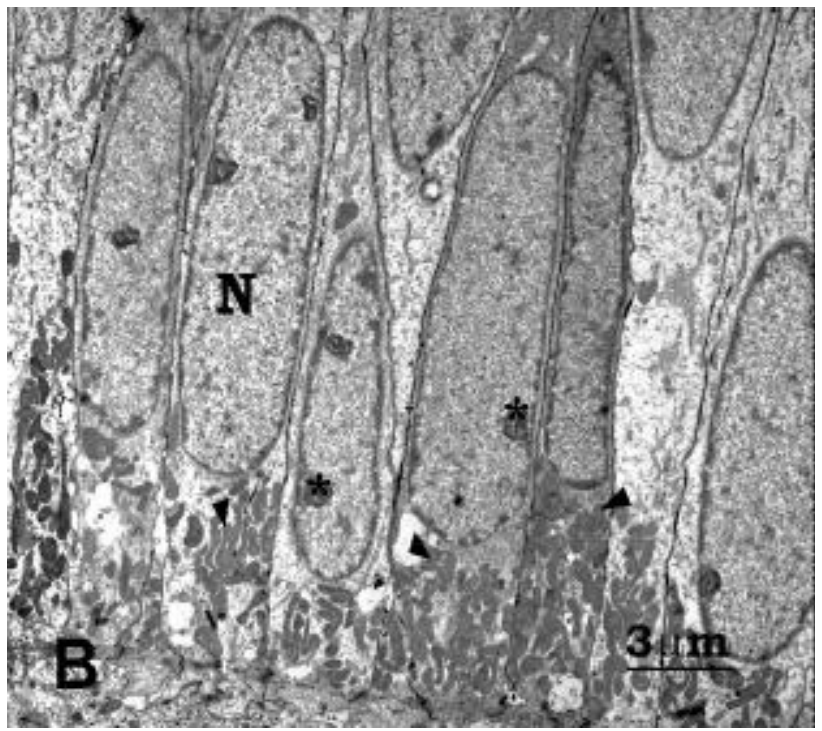

FIGURE 1- Secretory ameloblasts. A) Observe in the apical portion a great deal of RER (arrows), few secretory granules (circle) concentrated in Tomes' process $(T)$, next the enamel matrix $(M)$. In the Tomes' process, there were regions more electrodense, represented by junctional complex net (line). B) The basal portions is occupied by longer nucleus ( $\mathrm{N}$ ) showing an evident nucleolus (asterisk) and great deal of mitochondria (arrowheads) of several configurations.TEM; x12,000
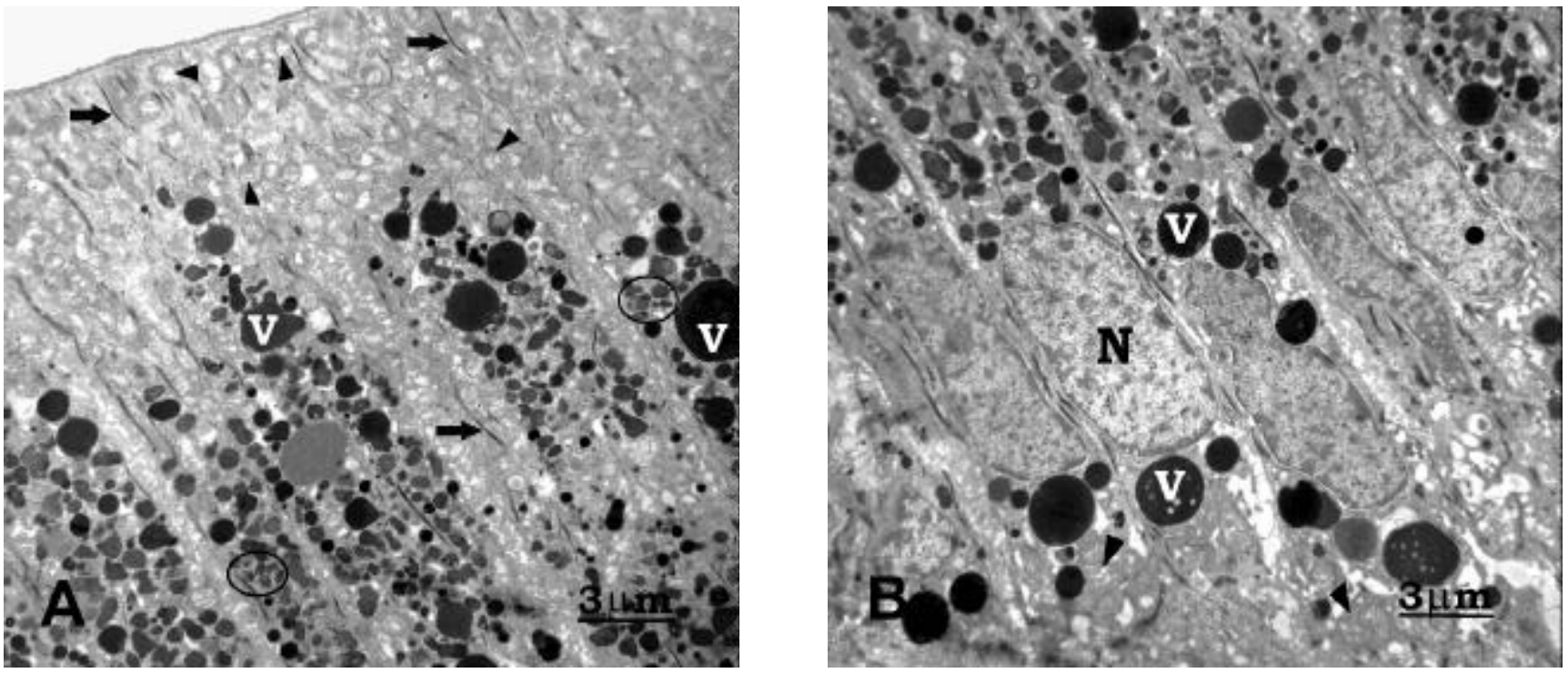

FIGURE 2-Maturation ameloblasts. A) Observe in apical portion a good deal of mitochondria with several configurations (arrowheads), and filaments (arrows) associated to desmossomes in all cytoplasm. In the media portion observe lysosomes (circles) and phagic vacuoles (V). B) In the basal portion observe ellipsoid nucleus $(\mathrm{N})$, little mitochondria (arrowheads) and little phagic vacuoles (V). TEM; $\times 12,000$ 
secretory to maturation ameloblasts in their volume density (for the $16.7 \%$ to $3.8 \%$ ), absolute volume $(74 \%)$, total surface $(90 \%)$ and surface-to-volume ratio $(59 \%)$. Whereas, for mitochondria, there was an increase in volume density (for the $3.64 \%$ to $28.22 \%$ ), absolute volume $(742 \%)$ and total surface $(384 \%)$, and a decrease in their surface-to-volume ratio (42\%).

\section{DISCUSSION}

Despite the various studies of the ameloblast biology using the remarkable techniques of molecular biology $y^{5,6,11,13}$, few studies in electron microscopy are available ${ }^{2-4,7,8,14-18}$ and morphometric investigation practically doesn't exist ${ }^{14}$.

In the present study, we found out some stereologic differences from secretory to maturation ameloblasts. Thus, the nuclear volume decreases, the cell height reduces and their width increase. According to earlier studies of Boyde; Reith ${ }^{2}$ (1977); Josephen; Fejerskov ${ }^{7}$ (1977) and Skobe ${ }^{18}$ (1980) probably, during amelogenesis, the nucleus accompanies the morphologic cytoplasm changes. As there is only one monolayer to produce and secrete several protein quantities and qualities and yet afterwards lead the mineral deposition, the ameloblasts show a longer form to increase the efficiency of all this activity. After the secretion of all the genetically programed enamel finishes, the cell diminish their height and increase

TABLE 1- The mean and standard deviation of morphometric parameters of the secretory and maturation ameloblasts

\begin{tabular}{|c|c|c|c|}
\hline Parameters & Secretory (A) & Maturation (B) & $A \times B^{*}$ \\
\hline \multicolumn{4}{|c|}{ Absolute Volume $\left(\mu \mathrm{m}^{3}\right)$} \\
\hline Nucleus & $398.6 \pm 10.12$ & $305.8 \pm 8.64$ & $P<0.05$ \\
\hline Cytoplasm & $2064.2 \pm 40.16$ & $2244.5 \pm 157.76$ & $P>0.05$ \\
\hline \multicolumn{4}{|c|}{ Volume Density (\%) } \\
\hline REG & $16.7 \pm 1.44$ & $3.8 \pm 1.92$ & $P<0.05$ \\
\hline Granules & $0.4 \pm 0.06$ & $* *$ & \\
\hline Lysosomes & $* *$ & $2.4 \pm 0.53$ & \\
\hline Phagic Vacuoles & ** & $8.8 \pm 4.35$ & \\
\hline Mitochondria & $3.6 \pm 0.07$ & $28.2 \pm 7.53$ & $P<0.05$ \\
\hline \multicolumn{4}{|l|}{ Total Volume $\left(\mu \mathrm{m}^{3}\right)$} \\
\hline REG & $344.4 \pm 28.85$ & $88.5 \pm 23.82$ & $P<0.05$ \\
\hline Granules & $9.0 \pm 1.21$ & $\star *$ & \\
\hline Lysosomes & ** & $54.0 \pm 16.14$ & \\
\hline Phagic Vacuoles & $* *$ & $199.9 \pm 101.74$ & \\
\hline Mitochondria & $75.2 \pm 2.42$ & $633.1 \pm 99.41$ & $P<0.05$ \\
\hline \multicolumn{4}{|l|}{ Total Surface $\left(\mu \mathrm{m}^{2}\right)$} \\
\hline REG & $3001.2 \pm 160.85$ & $289.4 \pm 107.86$ & $P<0.05$ \\
\hline Granules & $53.3 \pm 7.27$ & ** & \\
\hline Lysossomes & ** & $287.8 \pm 80.73$ & \\
\hline Phagic Vacuoles & $* *$ & $848.1 \pm 511.79$ & \\
\hline Mitochondria & $553.4 \pm 117.95$ & $2677.7 \pm 388.07$ & $P<0.05$ \\
\hline \multicolumn{4}{|c|}{ Surface-to-volume ratio $\left(\mu \mathrm{m}^{2} / \mu \mathrm{m}^{3}\right)$} \\
\hline REG & $8.9 \pm 0.85$ & $3.6 \pm 0.82$ & $P<0.05$ \\
\hline Granules & $6.8 \pm 2.12$ & ** & \\
\hline Lysossomes & $* *$ & $5.4 \pm 0.55$ & \\
\hline Phagic Vacuoles & $* *$ & $4.2 \pm 0.06$ & \\
\hline Mitochondria & $7.4 \pm 0.52$ & $4.2 \pm 0.06$ & $P<0.05$ \\
\hline
\end{tabular}

\footnotetext{
* Statistical probability level $\quad$ ** Don't appear or appear little.
} 
their width enhancing the withdrawal power of the matrix proteins. Although evident changes occur in this cell shape and in their intracytoplasmic structure, the cytoplasm volume remains unaltered.

On the other hand, the RER showed evident decrease in total volume $(74 \%)$ and total surface $(90 \%)$ from secretory to maturation ameloblasts. This role is likely explained by the fall in enamel protein production. The surface-to-volume ratio of the RER decreased 59\% showing that besides more volume and surface, the secretory ameloblasts RER cisterns are more flattened. During the secretion phase the quantity and diversity of structural and enzymatic proteins produced and secreted show a well-developed RER system and a well adapted Golgi complex. RER distributes its flattened cisternes to adequate its shape in the longitudinal way of the all cell and mainly to increase the efficiency in the protein production. Several formations of small Golgi complex are distributed in the ameloblast supranuclear portion and are difficult to be analized through stereology due to sparse distribuition of their dictiossomes. Though subjective analysis at TEM it is difficult to check some quantitative difference of this structure between two studied modulation ameloblast, but some authors affirm that this difference doesn't exist ${ }^{9,10}$.

We have noticed too the presence of secretory granules in secretory ameloblasts, as observed by Yamamoto $^{26}$ (1984). Their small diameters make their movements easier in the narrow citoplasm in this phase and because they are released constitutively, present a very low frequency, that doesn't reach $1 \%$. The movements are coordenated by the filaments, mainly of $\operatorname{actin}^{12}$.

As soon as the cells get modulated in the maturation ameloblasts, we have found out a great number of lysosomes and phagic vacuoles that are engaged in digestion of enamel matrix for latter enamel mineralization ${ }^{15-17}$. These ultrastructures occupy around $12 \%$ of the ameloblast citoplasm in maturation activity and are practically not seen in the secretion one. During the transition period between these two phases the lysosomes and the phagic vacuoles play an important role digesting selectively most of the organelles related to the proteic synthesis ${ }^{16}$.

Whereas, the total volume and total surface of mitochondria there was an increasing of $742 \%$ and $384 \%$, respectively, and their surface-to-volume ratio decreased $42 \%$. This last data shown that mitochondria of maturation ameloblasts are larger than in secretory ameloblasts, increasing their efficiency to obtain energy. As the RER quantity diminishes and the width of the cells increases the mitochondrias can expand to meet the greater energetic demand. Although they are found in all the cytoplasm, of the secretion ameloblast mitochondrias are found mainly in the basal region and the ones of the maturation phase concentrate more in the apical region due the metabolic features of each phase.

The preservation of the ameloblasts perpendicular shape mainly in the secretion phase and the several morphological differences that the cellular surface goes before and during the modulations are the results of constant morphogenetic induction ${ }^{1}$ and are dependent of the actin filaments activity and of the heat shock protein-25 (Hps-25) ${ }^{12}$.

The results described here confirmed that significant morphologic changes occur in ultrastructure ameloblasts during their modulation from the secretory to the maturation phase of enamel development, adapting to their new cellular function but although some evident changes in this cell shape and in their intracytoplasmic structure occur, the cytoplasm volume remains unaltered.

\section{RESUMO}

Ameloblastos são células de origem epitelial, que apresentam funções de síntese, secreção e maturação do esmalte dental. Assim sendo, ameloblastos passam por mudanças morfológicas durante o seu curso de desenvolvimento. Desse modo, cinco ratos adultos Wistar foram utilizados para avaliar a morfologia de ameloblastos da fase secretora e em maturação, usando de métodos estereológicos em microscopia eletrônica de transmissão. Os dados foram analisados pela análise de variância a um critério (ANOVA). Os resultados mostraram que da fase de secreção para a de maturação da amelogênese: a) ocorreu uma redução de $23 \%$ no volume absoluto nuclear e o volume absoluto citoplasmático não mostrou diferença estatisticamente significante $(\mathrm{p}>0.05) ; b)$ o volume total e a superfície total do retículo endoplasmático rugoso (RER) diminuíram $74 \%$ e $90 \%$, respectivamente; c) o volume total e a superfície total das mitocôndrias aumentaram $742 \%$ e $384 \%$, respectivamente; d) a relação superfície-volume do RER e das mitocôndrias diminuíram $59 \%$ e $42 \%$, respectivamente; e) os pequenos grânulos de secreção, dispostos principalmente na área apical, desapareceram junto com o Processo de Tomes e apareceram os lisossomos e vacúolos digestivos principalmente na área supranuclear. Portanto, apesar de ocorrer uma significante adaptação morfológica durante a modulação da fase secretora para a de maturação do 
desenvolvimento do esmalte, o volume citoplasmático do ameloblasto permanece inalterado.

UNITERMOS: Ameloblastos de secreção e de maturação; Incisivos de ratos, Estereologia; Ultraestrutura.

\section{REFERENCES}

1 - Anastasi G, Venza M, Cutroneo G, Valenti A, Santoro G, Trimarchi F.Ameloblast morphogenesis during amelogenesis. S.E.M. study. Bull Group Int Rech Sci Stomatol Odontol 2000; 42(1):11-22.

2 - Boyde A, Reith EJ. Scanning electron microscopy of rat maturation ameloblasts. Cell Tissue Res 1977; 178: 221-8.

3 - Boyde A, Reith EJ. Scanning electron microscopy of the lateral cell surfaces of rat incisors ameloblasts. J Anat 1976; 122: 603-10.

4 - Garant PR, Nalbandian J. Observations on the ultrastructure of ameloblasts with special reference to the Golgi complex and related components. J Ultrastruct Res 1968, 23: 427-43.

5 - Gritli-Linde A, Bei M, Maas R, Zhang XM, Linde A, McMahon AP.Shh signaling within the dental epithelium is necessary for cell proliferation, growth and polarization. Development 2002; 129(23):5323-37.

6 - Joao SM, Arana-Chavez VE. Expression of connexin 43 and $\mathrm{ZO}-1$ in differentiating ameloblasts and odontoblasts from rat molar tooth germs. Histochem Cell Biol 2003; 119(1):21-6.

7 - Josephen K, Fejerskov O. Ameloblast modulation in the maturation zone of the rat incisor enamel organ. A light and electron microscopy study. J Anat 1977; 124: 45-70.

8 - Katchburian E, Holt J. Studies on the development of ameloblasts. I. Fine structure. J Cell Sci 1972; 2: 415-47.

9 - Nanci A, Zalzal S, Kan FW. High-resolution scanning electron microscopy of rat incisor ameloblasts. Scanning Microsc 1993; $7(1): 165-74$

10 -Nanci A, Slavkin HC, Smith CE. Immunocytochemical and radioautographic evidence for secretion and intracellular degradation of enamel proteins by ameloblasts during the maturation stage of amelogenesis in rat incisors. Anat Rec 1987; 217(2):107-23.

11 -Nishikawa S. Colchicine-induced apoptosis and anti-Fas localization in rat-incisor ameloblasts. Anat Sci Int 2002; 77(3):17581

12 -Otsuka Y, Nakakura-Ohshima K, Noda T, Maeda T, Ohshima H. Possible role of heat shock protein (Hsp) 25 in the enamel organ during amelogenesis in the rat molar. Arch Histol Cytol 2001; 64(4):369-78.

13 -Ravindranath RM, Basilrose Sr RM, Ravindranath NH, Vaitheeswaran B.Amelogenin interacts with cytokeratin-5 in ameloblasts during enamel growth. J Biol Chem 2003 Mar 25 [epub ahead of print].
14 -Salama AH, Baley RL, Eisenmann DR, Zaki AE. Quantitative cytochemistry of lysossomal structures in rat incisor maturation enamel organ. Arch Oral Biol 1990; 35: 535-9.

15 -Salama AH, Zaki AE, Eisenmann DR. Tubular lysossomes in ruflle-ended ameloblasts associated with enamel maturation in rat incisor. J Histochem Cytochem 1989; 37: 801-11.

16 -Salama AH, Zaki AE, Eisenmann DR. Fine structural changes and lysosomal phosphatase cytochemistry of ameloblasts associated with the transitional stage of enamel formation in the rat incisor. Am J Anat 1991 Mar;190(3):279-90.

17 -Sasaki T. Endocytotic pathways at the ruffled borders of rat maturation ameloblasts. Histochemistry 1983; 80: 263-8.

18 -Skobe Z. Scanning electron microscopy of the mouse incisor enamel organ in transition between secretory and maturation stages of amelogenesis. Arch Oral Biol 1980; 25: 395-401.

19 -Smith CE, Nanci A. A method for sampling the stages of amelogenesis on mandibular rat incisors using the molars as a reference for dissection. Anat Rec 1989; 225: 257-66.

20 -Smith CE. Cellular and chemical events during enamel maturation. Crit Rev Oral Biol Med 1998; 9: 128-61.

21 -Ten Cate AR. Oral histology - development, structure and function. $5^{\text {th }}$ ed. Toronto: Mosby; 1998, p. 206-212

22 -Warshawsky H, Moore G. A techinique for the fixation and descalcification of rat incisors for electron microscopy. J Histochem Cytochem 1967; 15: 542-9.

23 -Weibel ER. Stereological methods - v. 1: Practical methods for biological morphometry. New York: Academic Press, 1979, p. 110187.

24 -Weibel ER. Stereological principles of morphometry in electron microscopic cytology. Int Rev Cytol 1969; 26: 235-302.

25 -Weibel ER, Kistler GS, Scherle WF. Pratical stereological methods for morfometric cytology. J Cell Biol 1966; 30: 23-38.

26 -Yamamoto K. Ultrastrucuture of granular materials in rat incisor enamel organ at early maturation stage. Arch Oral Biol 1984; 29: 157-9.

Recebido para publicação em: 20/01/2003

Aceito após reformulações em: 09/04/2003

All correspondence should be addressed:

Departamento de Ciências Biológicas - Histologia

Faculdade de Odontologia de Bauru - USP

Al. Octávio Pinheiro Brisolla, 9-75

Zip code: 17012-901

Bauru - SP, Brazil

Tel: (14) 2358259

e-mail: gfassis@fob.usp.br 